\title{
種々の不均一触媒により高級脂肪族エステル を水素化分解する際の微量副生物について
}

\author{
池田功・小 森 三 郎 \\ 大阪大学工学部応用化学科 (大阪市都島区東野田 9 丁目)
}
On the Slight Byproducts Generated in Catalytic Hydrogenolysis of Higher Fatty Ester using Various Heterogeneous Catalysts
Isao IKEDA and Saburō Komori
Dept. of Chem. Tech., Faculty of Eng., Osaka Univ.
(Higashinoda-9, Miyakojima-ku, Osaka)

Hydrocarbons generated in catalytic hydrogenoelysis of fatty ester and fatty alcohol have been previously determined.

In this paper, the author reported that the following, compounds as well as hydrocarbons mentioned above, were also detected by means of GLC :

a) hydrocarbons having higher carbon number than original fatty compounds.

b) olefin and aldehyde which have same carbon number as the original material.

c) dialkyl ether.

\section{1 緒言}

著者らは前報1に拈いて, 高級脂肪酸エステルの接触 還元によって高級アルコールを製造するときに副生する 炭化水素について報告した。原料脂肪族化合物と同炭素 数およびそれ以下の炭素数の炭化水素については確認, 定量することができたが，それ以外の微量生成物につい ては確認することができなかった。

今回ガスクロマトグラフィーを用い，さらに検討を加 えた結果, 原料脂肪族化合物よりも炭素数の増加した炭 化水素の生成が認められたほか, 高温, 高圧の水素の存 在下にもかかわらず, オレフィンやアルデヒドも相当量 生成残存しているのが認められ，またエーテルも微量な がら単離することができたので報告する。

\section{2 実験}

原料, 触媒抢よび還元反応はすべて前報と同様, メチ ルパルミテート, セチルアセテートおよびセチルアルコ 一ルを原料とし, 市販銅一クロム酸化物, 亜鉛一アルミ酸 化物, 亜鉛-ク口ム酸化物, 鉄-銅-アルミ酸化物, 酸化 第二鉄, 還元鉄, 酸化亜鉛, 酸化銅, 酸化クロム, アル ミナおよびラネーニッケルを触媒として用いた。

生成物の確認はガスクロマトグラフィーにより行なっ たが，採用した条件はカーボワックス $20 \mathrm{M} 10 \%$ を Diasolid L に付けたものを充テン剤とし，管は $2 \mathrm{~m} \times$ $4 \mathrm{~mm} \phi$, 水素ガス流量は $40 \mathrm{~m} l / \mathrm{min}$, 使用温度 $240^{\circ} \mathrm{C}$ で
あった。

生成物のガスクロマトグラムの一例を示すと Fig.-1 のようである。

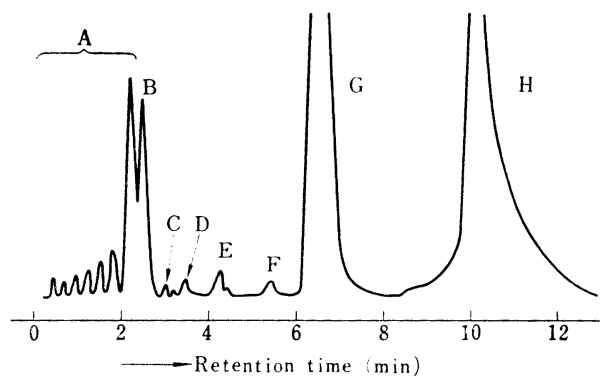

A: Hydrocarbons lower than heptadecane, B: Hexadecene $\mathrm{C}: \mathrm{C}_{17}$ hydrocarbon, $\mathrm{D}: \mathrm{C}_{18}$ hydrocarbon, $\mathrm{E}$ : Unidentified $\mathrm{F}:$ Palmitin aldehyde, $\mathrm{G}$ : Raw palmitic acid, $\mathrm{H}$ : Cetylalcohol

Fig.-1 An example of gas chromatogram of reduction products.

\section{3 実験結果および考察}

\section{生成物の確認、ヘキサデセン，ヘプタデカン，オク} タデカンおよびパルミチンアルデヒドの確認はつぎのよ うにして行なった。すなわち反応生成物を Fig.-2 のよ うにアルミナカラムクロマトにより四つの留分に分け, ヘキサン留分はガスクロマトグラフィーにより, 標準物 質々比較して, オクタデカン, ヘプタデカン, ヘキサデ センおよびへキサデカンその他の炭化水素であることを 認めた。 


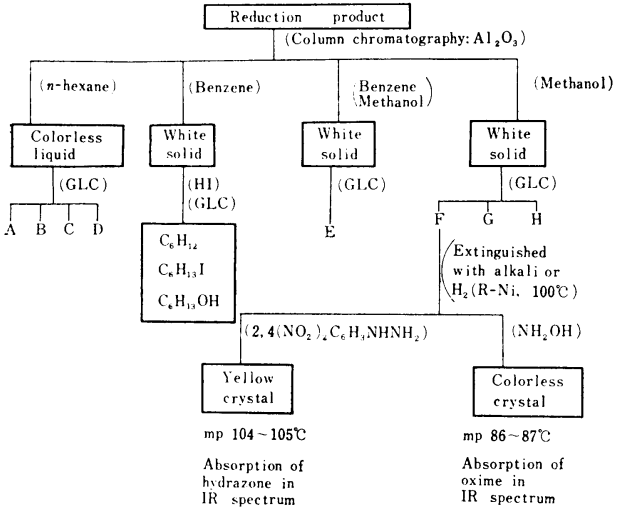

Fig.-2 Isolation of reduction product.

ベンゼン留分は本条件のガスクロマトグラムではピー クを示さないが， $1125 \mathrm{~cm}^{-1}$ にエーテルと思われる吸 収が認められるほか，ヨウ化水素酸処理によってへキサ デセン，ヘキサデシルョウ化物およびセチルアルコール が生成することを GLC によって確認できたので元の白 色固体はジへキサデシルエーテルであると認めた。

ベンゼンーメタノール留分 (E) はヒドロキシルアミ ン, 酸, アルカリに安定な物質であるが未確認である。

メタノール留分はおもに三つのピークからなり，Gお よびHはそれぞれ原料メチルエステルおよび高級アルコ ールであると認めた。

ピーク F はアルカリ処理あるいはラネーニッケルによ る水素化で容易に消滅するほか，ヒドロキシルアミンお よび 2,4-ジニトロフェニルヒドラジンでそれぞれ相当 するオキシムおよびヒドラゾンが得られることからピー ク $\mathrm{F}$ はパルミチンアルデヒドであると認めた。

銅一クロム酸化物触媒による脂肪酸エステルの水素化 分解の微量副生物について本 GLC 条件で確認できたも のを Table-1 に定性的に示した。

亜鉛一アルミ酸化物その他の 金属酸化物 およびラネー

Table-1 Slight byproducts produced in hydrogenolysis of fatty ester with $\mathrm{Cu}-\mathrm{Cr}-\mathrm{O}$ catalyst.

$\left(\begin{array}{l}\text { Reaction condition : Catalyst } 1.0 \mathrm{~g} \text {, raw material } \\ 10.0 \mathrm{~g}, \mathrm{H}_{2} \text { initial press at. room temp. } 160 \mathrm{~atm}\end{array}\right)$

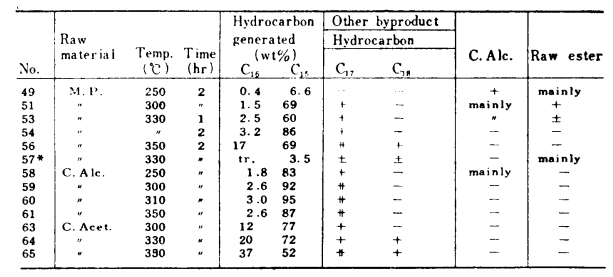

M.P. : Methyl palmitate, C. Alc. : Cetyl alcohol, P.A. : Palmitin aldehyde

* Carried out in $\mathrm{N}_{2}$ atmosphere
Table-2 Slight byproducts produced in hydrogenolysis of fatty ester with $\mathrm{Zn}-\mathrm{Al}-\mathrm{O}$ and other various metal oxides.

(Reaction condition: Catalyst $1.0 \mathrm{~g}$, raw material (methyl (palmitate) $10.0 \mathrm{~g}, \mathrm{H}_{2}$ initial press. at room temp. $160 \mathrm{~atm}$ )

\begin{tabular}{|c|c|c|c|c|c|c|}
\hline №. & $\begin{array}{l}\text { Cata- } \\
\text { lystemp. Time } \\
\text { (c) (hr) }\end{array}$ & 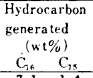 & $\begin{array}{l}\text { Other byproduct } \\
\text { Hydrocarbon } \\
\text { Clo }_{-}^{-} \\
\text {Olefin } C_{1}, \quad C\end{array}$ & E:**P.A & C. Alc. & $\begin{array}{l}\text { Raw } \\
\text { ester }\end{array}$ \\
\hline & 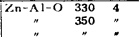 & $\begin{array}{cc}7.1 & 1.4 \\
13 & 7.7 \\
6.5 & 5.0\end{array}$ & "\# & $\frac{t}{ \pm}$ & ainly & $\underset{c}{ \pm}$ \\
\hline 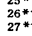 & 350 : & $\begin{array}{cc}11.6 & 6.0 \\
112 & 6.2 \\
13\end{array}$ & 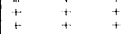 & & mainly & manly \\
\hline 30 & 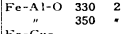 & $\begin{array}{ll}{ }_{35}^{29} & 50.9 \\
5 & 10\end{array}$ & $\div$ & & : & $\begin{array}{l}\operatorname{manin} l y \\
++\end{array}$ \\
\hline 32 & $\begin{array}{ll}A 1-0 & 330 \\
330 & \end{array}$ & $\begin{array}{ll}2.3 & 1.5 \\
42 & 2.3\end{array}$ & \pm & + & 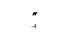 & $\therefore$ \\
\hline & 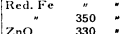 & $\begin{array}{ll}28 & 2.1 \\
87 & 7.6 \\
87.6\end{array}$ & $\therefore$ & $\because$ & $\operatorname{manin} 1 s$ & 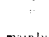 \\
\hline $\begin{array}{l}36 \\
37 \\
38\end{array}$ & $\begin{array}{rr}350 \\
7 n-C r-O & 330 \\
350\end{array}$ & $\begin{array}{rr}24.5 & 1.4 \\
3.5 & 1.1 \\
99 & 27\end{array}$ & ; & & mextinly & 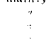 \\
\hline 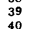 & $\mathrm{Al}_{2} \mathrm{O}_{3}$ & $\begin{array}{ll}3.7 & 0.7\end{array}$ & H & & " & mainly \\
\hline 41 & $\mathrm{Fe}_{\mathrm{Fe}_{2} \mathrm{O}_{3}}{ }_{330}^{350}$ & $\begin{array}{cc}10 & 0.9 \\
1.4 & 0.9\end{array}$ & + & $\neq$ & $\because$ & : \\
\hline${ }_{45}^{44}$ & cuö & $\begin{array}{rr}8.0 & 5.8 \\
14 & 1.1\end{array}$ & 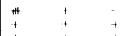 & & $\stackrel{\substack{\text { matinly } \\
+}}{+}$ & mainiy \\
\hline${ }_{48}^{47}$ & $\mathrm{Cr}_{2}{ }_{2} \mathrm{O}$, & $\begin{array}{cc}13 & 1.1 \\
7.5 & 6.2\end{array}$ & 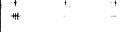 & & $\operatorname{main} 1 v$ & \\
\hline & 350 & $11 \quad 7.0$ & 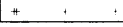 & & & \\
\hline
\end{tabular}

${ }^{*}$ Carried out at $\mathrm{N}_{2}$ atmosphere

** Cetyl Alcohol was used as raw material

*** $\mathrm{E}$ : Unknown material P.A. : Palmitin Aldehyde

Table-3 Slight byproducts produced in hydrogenolysis of fatty ester with Raney Nickel.

(Reaction condition : Catalyst $1.0 \mathrm{~g}$, raw material

$\left(\begin{array}{l}10.0 \mathrm{~g}, \mathrm{H}_{2} \text { initial press. room temp. } 100 \mathrm{~atm}\end{array}\right)$

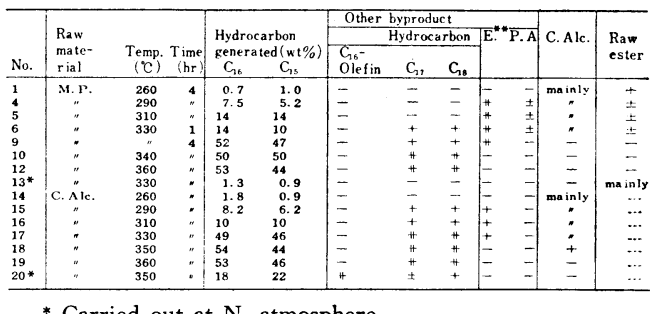

* Carried out at $\mathrm{N}_{2}$ atmosphere

ニッケルによる水素化分解生成物中の微量副生物を

Table-2, 3 に定性的に示した。

ラネーニッケルを用いた場合, 副生成物の種類は比較 的少なく, 炭素数 16 以下の低級炭化水素以外にはへブ タデカンおよびオクタデカンの副生をみたのみである。

ニッケルによる脂肪族化合物の増炭反応はあまり類例

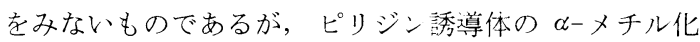
などにみられる2)ような，脱メチロールにより生成した 炭素数の少ない切断物のカップリングによるものと考え られる。ほかの金属酸化物による堌炭反忘も同様の過程 によるものと考えられる。

酸触媒によるイオン重合の場合には分解と結合がしば しば起こるが，金属酸化物触媒によっても $300^{\circ} \mathrm{C}$ 付近 で炭素-炭素結合の分解と再結合が起こっていることは 注目すべきことである。

(昭和 41 年 6 月 4 日受理)

\section{文献}

1）池田，服部，小森，油化学， 14, 510 (1965)

2) M.G. Reinecke, L.R. Kray, J. Am. Chem.Soc., 86, 5355 (1964) 